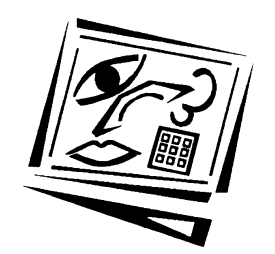

\title{
Students' expectations of the learning process in virtual reality and simulation-based learning environments
}

Tuulikki Keskitalo

University of Lapland

\begin{abstract}
Expectations for simulations in healthcare education are high; however, little is known about healthcare students' expectations of the learning process in virtual reality (VR) and simulation-based learning environments (SBLEs). This research aims to describe first-year healthcare students' (N=97) expectations regarding teaching, studying, and learning in such environments. In addition, it measures students' expectations of instructors, their academic self-perception, and atmosphere, as well as whether there are differences between the expectations of adult and young students. Data was collected through a questionnaire from two different universities of applied sciences in Finland in spring 2009, and analysed using statistical and qualitative methods. Overall, students have quite high expectations of the activities that take place in VR and SBLEs. Adult learners in particular seem to have high expectations compared to younger students.
\end{abstract}

\section{Introduction}

Healthcare educators have long used simulations to enhance patient safety. These simulations vary from a simulated operating theatre with a sophisticated, high-fidelity human patient simulator, to a human who acts as a simulated patient (Bradley, 2006). These days, advances in technology have made it possible to create simulations that fully engage learners in the environment and the learning process (Bradley, 2006; Cobb \& Fraser, 2005). Thus, the utilisation of virtual realities (VRs) in healthcare education is also growing rapidly (Kneebone, 2003; Rosen, 2008).

In recent years, interest has grown in examining students' expectations and perceptions of the educational environment in medical schools since learning environments are in many ways related to students' behaviour, academic achievements, satisfaction, and aspiration (Miles \& Leinster, 2007). However, research related to expectations about the learning process in VR and simulation-based learning environments (SBLEs) remains absent. Expectations for simulations are high in healthcare education; their use is expected to improve patient care and enhance patient safety. In healthcare education, simulations are expected to improve learning and provide students with experiential learning opportunities (Cleave-Hogg \& Morgan, 2002; Gaba, 2004; Loke, Blyth \& Swan, 2012; Rall \& Dieckmann, 2005). Simulations potentially provide a safe and realistic learning environment in which repeated practice is possible. Additionally, some expect simulations to enable the integration of theory into practice (Issenberg, McGaghie, Petrusa, Gordon \& Scalese, 2005; Rall \& Dieckmann, 2005). 
This research aims to describe healthcare students' $(\mathrm{N}=97)$ expectations regarding teaching, studying, and learning in VR and SBLEs prior to experiencing them. It also examines the kind of expectations students have of their instructors, atmosphere, and themselves as learners. Here, studying and learning are used separately because the purpose is to emphasise students' active role in the learning process. That is, teaching does not always lead to learning; rather students' own activities are also necessary (Kansanen et al., 2000; Uljens, 1997). The data was collected from two different universities of applied sciences in Finland in spring 2009, using mixed methods. The questionnaires' open answers were analysed qualitatively and used to support the quantitative analysis. This article is part of a larger study whose overall aim is to develop a pedagogical model for VR and SBLEs using design-based research methods (Brown, 1992; Design-based Research Collective, 2003; see also Keskitalo, Ruokamo \& Väisänen, 2010). The first phase consisted of thematic interviews with teachers. The goal was to determine the kinds of pedagogical approaches and educational tools teachers have adopted when teaching in VR and SBLE (Keskitalo, 2011). In this second phase, the aim is to learn about students' expectations of the learning process in VR and SBLEs (see also Keskitalo, 2009). This should enable the design of a user-friendly pedagogical model and ensure its integration into healthcare education practice.

The overall aim of this research is to change pedagogical practices in VR and SBLEs by embedding learning theoretical views into teaching practice, because previous research has shown that healthcare education remains somewhat intuition and opinion-based (Ramani, 2006). In other words, teachers are using their opinions or intuition to determine their pedagogical methods. What follows is an introduction to the literature, research questions, and methods. The last section presents and discusses the research results.

\section{Literature review}

\section{Previous studies of students' expectations}

In this study, the term "expectations" refers to students' expectations regarding the learning process in VR and SBLEs. Many definitions are used to describe expectations within the service delivery sectors (Higgs, Polonsky \& Hollick, 2005; Shewchuk et al., 2007). Expectations could be expected or predictive, which, in this study, could be students' predictions of or beliefs about teaching and studying in VR and SBLEs. In other words, what will occur in these learning environments? Normative expectations are expectations about what should occur in VR and SBLEs (Higgs et al., 2005; Shewchuk et al., 2007). There are also experience-based expectations, which are expectations that follow prior experience, in this case, healthcare education or practice (Parasuraman, Zeithaml \& Berry, 1988).

In medical and healthcare education, the existing research literature related to students' expectations of teaching and learning in VR and SBLEs is limited. So far, the research that has been done relates to medical students' perceptions of their educational environment (Amin, Tani, Eng, Samarasekara \& Huak, 2009; Miles \& Leinster, 2007) and their expectations for their future medical practice (Draper \& Louw, 2007; O'Connell \& Gupta, 2006). One study tried to develop a standardised approach to assessing physicians' expectations and perceptions about continuing medical education (Shewchuk et al., 2007). Miles and Leinster (2007) studied first-year medical students' expectations about the learning environment and compared those 
results to the students' actual perceptions. Their results revealed that students initially encounter their learning environment with high expectations, although they do not expect the learning environment to be perfect. Overall, students' expectations for learning and teachers, and their academic self-perception and social self-perception were higher than their actual perceptions. In particular, the study found that teachers were worse at providing feedback than students expected and did not provide the constructive criticism that students expected. The learning objectives were also unclear to students, the school schedule was not scheduled as well as they expected, and the support system for stressed students was poorer than they had expected. In their study, Miles and Leinster (2007) used the revised Dundee Ready Education Environment Measure (DREEM) (Roff et al., 1997) to measure medical students' expectations about their educational environment.

In Draper and Louw's (2007) study, most medical students found the curriculum's content contrary to their expectations. They expected their medical degree to be mostly biomedical and scientific in content, and did not expect the curriculum's psychosocial component to be a feature of studying medicine. These students viewed the medical profession as significant and influential. Also, O'Connell and Gupta (2006) found that despite the challenges of practising medicine, students have realistic perceptions of the current medical practice environment.

\section{Teaching and learning in virtual reality and simulation-based learning environments}

The apprenticeship model has long been used in medical and healthcare education to teach basic principles and skills to novice learners (Kneebone, 2003; Kneebone, Scott, Darzi \& Horrocks, 2004). In the traditional apprenticeship model, an apprentice views the master executing a task, and then the apprentice tries to execute the task with the master's guidance and help (Rogoff, 1990). The main problem with this model has been the issue of patient safety because students were practising with real patients. Nowadays, problem-based learning (PBL) has become a popular approach to teaching in medical and healthcare education (e.g., Barrows \& Tamblyn, 1980). PBL sees learning as a problem-solving process in which students deal with authentic and illstructured problems that originate in real-life work. During the learning process, teachers work mostly as tutors or facilitators and support students' learning, whereas students work in groups and engage in self-directed learning (Hmelo-Silver, 2004; Hmelo-Silver \& Barrows, 2006). These approaches are based mainly upon experiential learning approaches (Hmelo-Silver, 2004), for example, Kolb's (1984) experiential learning model that views learning as a continuous process grounded in experience. In addition, PBL utilises the ideas of social-constructivism and socio-cultural theory (Lave \& Wenger, 1991; Tynjälä, 1999; Vygotsky, 1978).

Simulators and simulations have been introduced to healthcare education because of their ability to provide students with experiential learning opportunities and a safe practice environment (Cleave-Hogg \& Morgan, 2002). In simulation settings, a typical course structure consists of an introduction, simulator briefing, scenarios, debriefing, and course ending (Dieckmann, Gaba \& Rall, 2007; Joyce, Calhoun \& Hopkins, 2002). According to Joyce and associates' (2002) Learning through simulations model, in the introductory phase, the teacher presents the course topic and the most important concepts, and explains the simulation concept to students. This phase also includes explanations of how the course is organised, and the kinds of pedagogical models and 
methods it uses. During the simulator briefing, the participants begin to get into the simulation. This is the phase in which the teacher introduces the scenario. As a learning trigger, the teacher uses either problems or real-world examples. The second phase includes the introduction of the simulation's goals, the participants' roles, the rules and procedures they have to follow, and the decisions they have to be able to make during the scenario. At the end of the second phase, the teacher ensures that everybody has understood the instructions. In phase three, students participate in the simulation. During this phase, students are active while the teacher functions as a facilitator or instructor by giving feedback, correcting misunderstandings, and evaluating students' performance and decisions. However, comprehensive evaluations and reflections occur during the debriefing phase when the teacher encourages students to analyse the whole process, including how the scenario went, what problems they encountered, and what they learned. In this phase, it is important for students to compare the simulation to the real world.

\section{Research questions}

With these theories and the cited literature as background, this study focuses on students' expectations related to teaching, studying, and learning processes in VR and SBLEs. The following research questions were set:

- What kinds of expectations do students have about teaching, studying, learning, and instructors in VR and simulation-based learning environments?

- What kinds of expectations do students have of their academic self-perception and atmosphere in VR and simulation-based learning environments?

- Are there differences between the expectations of adults and those of young students?

\section{Methods}

\section{Data collection}

This research collected data using a questionnaire given to the students ( $\mathrm{N}=97)$. This questionnaire was partially based on the DREEM (Roff et al., 1997) as well as other questionnaires that have been developed to measure meaningful learning (Nevgi \& Löfström, 2005; Hakkarainen, 2007). The original DREEM was a 50-statement questionnaire which was developed to measure the educational environment of health professions. DREEM's statements were divided into five subscales, namely students perception of teaching, teachers, academic self-perception, atmosphere, and social selfperception. However, for the purpose of this research, some questions from the original DREEM were eliminated and questions regarding the expectations of studying and learning were added, since the original DREEM examines mainly the perceptions of teaching. The additional questions were used to measure the expectations of the meaningfulness of learning (Nevgi \& Löfström, 2005; Hakkarainen, 2007), which provided essential information for the design of the pedagogical model (Keskitalo et al., 2010). Some statements from the DREEM were also revised for this research, for example, "I am confident about passing this year" was changed to "I am confident about passing this course," or "The atmosphere is relaxed during the ward teaching" was changed to "During the debriefing, the atmosphere will be relaxed." The original DREEM questions that were eliminated were considered unsuitable for the purpose of 
this research, e.g., the questions "Cheating is a problem in this school" or "The teachers get angry in class" were considered irrelevant for our purpose. The sub-scale, "Students' social self-perception," was almost completely omitted since it was considered irrelevant. However, one statement was reworded from "There is a good support system for students who get stressed" to "Embattled students will get help," and removed to the sub-scale in our questionnaire that measures atmosphere.

Finally, to check the meaningfulness of the questionnaire, 10 students from the Rovaniemi University of Applied Sciences completed the questionnaire and gave us feedback. Thereafter, a tentative analysis and final revisions were made. These test questionnaires were not included in this research. The final questionnaire asked students for background information and questions related to their expectations of teaching, studying, and learning processes in VR and SBLEs. In addition, it measured students' expectations regarding their instructor, academic self-perception, and atmosphere. Each of the 65 statements was scored on a continuum, in which $1=$ "the statement does not describe my expectations at all," 2 = "the statement describes my expectations some," $3=$ "the statement describes my expectation neither poorly nor well," 4 = "the statement describes my expectations quite well," and $5=$ "the statement describes my expectations well." Also, one open question gave the students opportunity to write about any other expectations they had. In this research, all the activities were conducted in Finnish, and the translations into English were made by the author and checked by a native-speaking transcription service.

The data was collected at Rovaniemi University of Applied Sciences (Rovaniemi, Finland) and Arcada University of Applied Sciences (Helsinki, Finland, http: / / apslc.arcada.fi/) in January and February 2009. Both schools have simulation centres consisting of separate rooms where students can practise specific skills or go through entire scenarios related to the content areas. When studying, one room is usually decorated for the students' rehearsal, and contains a patient simulator and a monitor displaying the vital signs of the patient simulator. Next to this room is a space for the facilitator, where he or she can control the simulator and guide the students' learning process via audio devices. One room is dedicated to debriefing and contains appropriate technology, such as video and audio recording devices, which can be used in debriefing sessions to complement the students' reflection. The simulation centre situated at the Rovaniemi University of Applied Sciences (known as ENVI, see http: / / www.envi.fi/) also includes an immersive full-scale 3-D (three-dimensional) incident environment simulation projection, in which users can view, navigate, and interact with a handheld device (for detailed description, see Keskitalo, 2011). Therefore, ENVI is kind of a mixed-reality learning environment as it combines physical environment and simulation manikins with 3-D simulation projection (see Haukkamaa, Yliräisänen-Seppänen \& Timonen, 2010). The idea of ENVI is that healthcare students or professionals can practice cooperation during the entire healthcare process, from the scene of an accident, to a hospital, and finally, to rehabilitation. However, this research did not analyse the influences of the type of simulation centre; it focused instead on the students' expectations of the learning process in these environments.

The participants were first-year healthcare students who were chosen because they had little experience with training in VR and SBLEs, though they were expecting to train in this type of learning environment in the future. The purpose of choosing them on this basis was to guarantee that their experiences did not affect their expectations. The participants volunteered to take part and had an opportunity to refuse or 
withdraw from the study at any time. The participants received no compensation for taking part in the study.

\section{Data analysis}

The quantitative data was analysed using SPSS 15.0 for Windows. Altogether, 97 students volunteered to take part in the study, 82 of whom (84.5\%) were female and 15 $(15.5 \%)$ male. The respondents' mean age was 27 years. The youngest respondent was 19 and the oldest was 53 years old. Sixty-one of the respondents $(62.9 \%)$ were nursing students. In addition, some of the students were studying paramedics $(n=2 ; 2.1 \%)$, physiotherapy $(\mathrm{n}=17 ; 17.5 \%)$, occupational therapy $(\mathrm{n}=5 ; 5.2 \%)$, and healthcare $(\mathrm{n}=9$; 9.3\%). The data was analysed using factor analysis and reliability analysis (Cronbach's alpha). For the factor analysis, the statements were selected based on previous studies. However, as a result of the analysis, some statements that belonged to the original DREEM or the questionnaires that measured meaningful learning were discarded. Based on the results of factor analysis and reliability analysis, the sum variables were computed using a mean of the items within the sub-scale. For the analysis, the sum variable was also categorised into five categories $(1=$ no expectations, $2=$ a little expectations, $3=$ neither little nor a lot expectations, $4=$ quite a lot of expectations, $5=$ a lot of expectations) to get a better understanding of the level of the participants' expectations. Kolmogorov-Smirnov tests, instead of $\mathrm{t}$-tests, were used to determine whether there were differences in expectations between adult and young students, because the distribution of the test variables was skewed. The individual items' means and standard deviations were also reported. The qualitative data was analysed and used to support the quantitative analysis.

\section{Results}

\section{Students' expectations of the learning process in VR and SBLEs}

The first research question was concerned with the kinds of expectations students have regarding teaching, studying, learning, and instructors in VR and SBLEs. Table 1 presents the factors and the statements with the means and standard deviations that belong to each factor (with the loadings of 0.517 to 0.890 ). Cronbach's alpha for each factor is included in the table along with the means and standard deviations of the sum variables, which are the empirical counterparts of the factors.

The results showed that Cronbach's alpha values were all above 0.7 (0.861 to 0.897), which indicates both an acceptable internal consistency and that the variables can be used to describe students' expectations (Nunnally, 1978). As the results indicate, students' expectations of teaching $(\mathrm{M}=3.65 ; \mathrm{SD}=0.54)$ in VR and SBLEs were quite high; $49.5 \%$ of the respondents had quite high expectations of teaching in these environments, and $5.2 \%$ expected a lot. Most often, students expected that teaching would help to develop their competence $(\mathrm{M}=4.16$; $\mathrm{SD}=0.83)$, would be stimulating $(\mathrm{M}=3.99 ; \mathrm{S}=0.92)$, and that students' needs were the starting point for teaching $(\mathrm{M}=3.86$; $\mathrm{SD}=0.97)$. Therefore, the variable was named "Inspiring and individuallytailored teaching". This result was expected because many previous researchers have indicated that students enjoy simulation exercises and the opportunities provided to practise skills before encountering the real situations (Cleave-Hogg \& Morgan, 2002; Holzman et al., 1995; Moule, Wilford, Sales, \& Lockyer, 2008), which the following excerpts also confirm: 
Table 1: Statements, Cronbach's alpha, means and standard deviations for each factor

\begin{tabular}{|c|c|c|c|}
\hline Factor & Statements in the questionnaire & $\begin{array}{l}\text { Cronbach's } \\
\text { alpha for } \\
\text { each factor }\end{array}$ & $\begin{array}{l}\text { Means (M) } \\
\text { and SD of the } \\
\text { sum variable }\end{array}$ \\
\hline \multirow{7}{*}{$\begin{array}{l}\text { Inspiring } \\
\text { and } \\
\text { individually } \\
\text {-tailored } \\
\text { teaching }\end{array}$} & 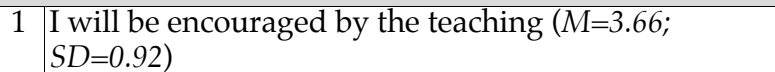 & \multirow[t]{7}{*}{0.897} & \multirow[t]{7}{*}{$\begin{array}{l}\mathrm{M}=3.65 \\
\mathrm{SD}=0.54\end{array}$} \\
\hline & 2 The teaching will be stimulating $(M=3.99 ; S D=0.92)$ & & \\
\hline & $3 \begin{array}{l}\text { Students' needs are the starting point for teaching } \\
(M=3.86 ; S D=0.97)\end{array}$ & & \\
\hline & $\begin{array}{l}4 \text { The teaching will help to develop my competence } \\
(M=4.16 ; S D=0.83)\end{array}$ & & \\
\hline & $\begin{array}{l}5 \text { The teaching will help to develop my confidence } \\
(M=3.56 ; S D=1.03)\end{array}$ & & \\
\hline & $6 \begin{array}{l}\text { The teaching takes students' individuality into } \\
\text { account }(M=3.17 ; S D=1.02)\end{array}$ & & \\
\hline & $\begin{array}{l}7 \text { The teaching encourages me to be an active learner } \\
(M=3.67 ; S D=0.98)\end{array}$ & & \\
\hline \multirow{9}{*}{$\begin{array}{l}\text { Individual } \\
\text { and compet- } \\
\text { ence-based } \\
\text { studying }\end{array}$} & $\begin{array}{l}1 \text { In lessons, students have the opportunity to actively } \\
\text { acquire, evaluate, and apply information }(M=3.67 ; \\
S D=0.98)\end{array}$ & \multirow[t]{9}{*}{0.862} & \multirow[t]{9}{*}{$\begin{array}{l}\mathrm{M}=3.91 \\
\mathrm{SD}=0.64\end{array}$} \\
\hline & $2 \begin{array}{l}\text { While studying in a simulation-based learning } \\
\text { environment, I have the ability to utilise my prior } \\
\text { knowledge }(M=4.03 ; S D=0.86)\end{array}$ & & \\
\hline & $3 \begin{array}{l}\text { I have the opportunity to set my own goals for } \\
\text { studying }(M=4.02 ; S D=0.86)\end{array}$ & & \\
\hline & \begin{tabular}{l|l} 
With the instructor's guidance, I have the \\
opportunity to practise my skills $(M=3.76 ; S D=1.05)$
\end{tabular} & & \\
\hline & $\begin{array}{l}5 \begin{array}{l}\text { When studying, I have the opportunity to take } \\
\text { advantage of my prior experiences }(M=3.93 \text {; } \\
S D=0.80)\end{array}\end{array}$ & & \\
\hline & $6 \begin{array}{l}\text { During the course, I have the opportunity to } \\
\text { familiarise myself and practise with the equipment I } \\
\text { will need in my future work }(M=4.16 ; S D=1.13)\end{array}$ & & \\
\hline & $7 \begin{array}{l}\text { During the lessons I have the possibility to } \\
\text { repeatedly practise my skills }(M=3.66 ; S D=0.90)\end{array}$ & & \\
\hline & $8 \begin{array}{l}\text { While studying in a simulation-based learning } \\
\text { environment, I can feel safe }(M=3.98 ; S D=0.83)\end{array}$ & & \\
\hline & $9 \begin{array}{l}\text { During the lessons, I have the opportunity to } \\
\text { critically evaluate my own learning }(M=3.92 ; \\
S D=0.90)\end{array}$ & & \\
\hline \multirow{5}{*}{$\begin{array}{l}\text { Transferable } \\
\text { learning } \\
\text { outcomes }\end{array}$} & 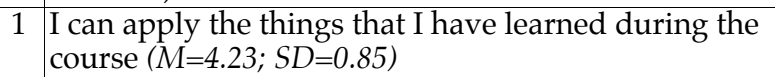 & \multirow[t]{5}{*}{0.861} & \multirow[t]{5}{*}{$\begin{array}{l}\mathrm{M}=4.09 \\
\mathrm{SD}=0.73\end{array}$} \\
\hline & $2 \begin{array}{l}\text { The things that I learn in a simulation-based } \\
\text { learning environment help me to understand things } \\
\text { better than I did before }(M=4.23 ; S D=0.80)\end{array}$ & & \\
\hline & $\begin{array}{l}3 \begin{array}{l}\text { I believe that using the equipment I need in my } \\
\text { work will be easier after this course than it was } \\
\text { before }(M=4.13 ; S D=0.91)\end{array}\end{array}$ & & \\
\hline & $4 \begin{array}{l}\text { My problem-solving skills will develop during this } \\
\text { course }(M=3.66 ; S D=1.06)\end{array}$ & & \\
\hline & $\begin{array}{l}5 \\
\begin{array}{l}\text { Studying in a simulation-based learning } \\
\text { environment will develop my skills }(M=4.18 ; \\
S D=0.91)\end{array}\end{array}$ & & \\
\hline
\end{tabular}




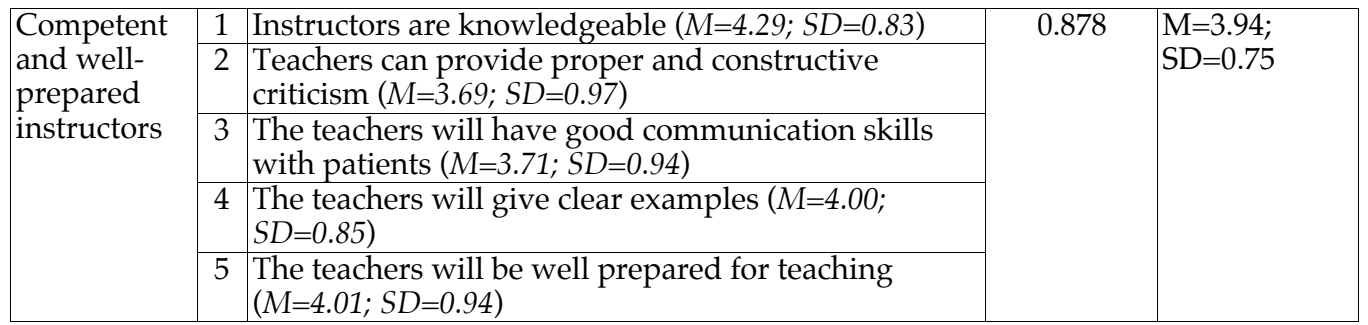

I expect enthusiastically to get into an ENVI environment; we have not yet been in the ENVI. I expect that I will test and practise different kinds of situations and tricks. (Student, number 6)

It is nice that we can practise in a simulated situation before being with real patients. I am sure that I am not as nervous as I would be if there was no simulated training. (Student, number 40)

Students had quite high expectations of studying ( $\mathrm{M}=3.91 ; \mathrm{SD}=0.64)$ too; $67 \%$ of the respondents expected quite a lot or a lot. As the sum variable's name ("Individual and competence-based studying") indicates, students particularly expected to be able to utilise their prior knowledge $(\mathrm{M}=4.03 ; \mathrm{SD}=0.86)$ and set their own goals for studying $(\mathrm{M}=4.02$; $\mathrm{SD}=0.86$ ). Students also expected to have the opportunity to familiarise themselves and practise with the equipment they would need in their future work $(M=4.16$; $S D=1.13)$, although, on this question, the standard deviation was quite high. This indicates that some of the students expected that they could familiarise themselves and practise with the equipment, but others had lower expectations in this regard. As these results indicate, students expected their studying to be constructivist and self-directed in nature. Constructivist learning means that learners build meaningful knowledge upon their previous knowledge (e.g., Jonassen, 1995; Tynjälä, 1999); self-directed learning assumes that learners can set their own goals for learning and be responsible for achieving them (e.g., Knowles, 1975).

"Transferable learning outcomes" was used to describe the expectations for learning $(\mathrm{M}=4.09 ; \mathrm{SD}=0.73)$ in these environments. Individual items indicate that most often students expected to learn things that were applicable $(\mathrm{M}=4.23$; $\mathrm{SD}=0.85)$, and that learning in VR and SBLEs would help them to understand things $(\mathrm{M}=4.23 ; \mathrm{SD}=0.80)$. In addition, students expected the use of equipment to be easy $(\mathrm{M}=4.13 ; \mathrm{SD}=0.91)$ and that they would become highly skilled $(\mathrm{M}=4.18$; $\mathrm{SD}=0.91)$ after the course. These expectations might come true; previous studies have shown that students benefit from simulation-based training. For example, in Moule and associates' (2008) study, students learned skills, but they also felt that training in a simulation-based environment increased their knowledge and understanding of the subject matter. Overall, $41.2 \%$ of the respondents expected quite a lot and $32 \%$ expected a lot from learning in these environments.

Students expected quite a lot from instructors $(\mathrm{M}=3.94 ; \mathrm{SD}=0.75)$ as well; $33.0 \%$ of the students expected quite a lot from their instructors, and $26.8 \%$ expected a lot. Students especially expected their instructors to be competent $(\mathrm{M}=4.29 ; \mathrm{SD}=0.83)$ and well prepared for teaching $(\mathrm{M}=4.01 ; \mathrm{SD}=0.94)$, and to give clear examples $(\mathrm{M}=4.00$; $\mathrm{SD}=0.85)$. Therefore, the sum variable was titled "Competent and well-prepared instructors." Amin et al. (2009) also found similar results when they measured the characteristics of university teachers in medical school. The characteristics that 
students valued most were being knowledgeable about the subject matter, being friendly and approachable, and having well-organised teaching materials.

These results place high demands on the instructors. The instructor's role in simulation-based training is quite different from that of traditional lecture-based instruction. Research has indicated that instructors need development, especially regarding different kinds of pedagogical methods (Keskitalo, 2011) and in how to facilitate debriefing (Østergaard, Østergaard \& Lippert, 2004).

\section{Students' expectations of their academic self-perception and atmosphere}

The second research question concerned the kinds of expectations and perceptions students have of their academic self-perception and atmosphere in VR and SBLEs. Table 2 presents the factors and the statements with the means and standard deviations that belong to each factor (with the loadings of 0.825 to 0.835 ). Cronbach's alphas for each factor and the means and standard deviations of the sum variables are also included in the table.

Table 2: Statements, Cronbach's alpha, means and standard deviations for each factor

\begin{tabular}{|c|c|c|c|}
\hline Factor & Statements in the questionnaire & $\begin{array}{l}\text { Cronbach's } \\
\text { alpha value } \\
\text { for each } \\
\text { factor }\end{array}$ & $\begin{array}{c}\text { Means (M) } \\
\text { and SD of } \\
\text { the sum } \\
\text { variable }\end{array}$ \\
\hline \multirow{5}{*}{$\begin{array}{l}\text { Confident and } \\
\text { competent } \\
\text { students } \\
\text { (academic self- } \\
\text { perception) }\end{array}$} & $1 \quad \begin{array}{l}\text { I am confident about passing this course }(\mathrm{M}=3.73 \text {; } \\
\mathrm{SD}=0.84)\end{array}$ & \multirow[t]{5}{*}{0.835} & \multirow[t]{5}{*}{$\begin{array}{l}\mathrm{M}=3.51 \\
\mathrm{SD}=0.70\end{array}$} \\
\hline & $2 \begin{array}{l}\text { I believe that I will be well prepared to practise my } \\
\text { profession }(\mathrm{M}=3.46 ; \mathrm{SD}=1.01)\end{array}$ & & \\
\hline & $\begin{array}{l}3 \text { I believe that I can manage different kinds of } \\
\text { exercises }(M=3.86 ; S D=0.85)\end{array}$ & & \\
\hline & $\begin{array}{l}4 \text { I will be able to memorise all I need from this course } \\
(\mathrm{M}=3.12 ; \mathrm{SD}=0.92)\end{array}$ & & \\
\hline & $5 \begin{array}{l}\text { Learning strategies that have worked for me before } \\
\text { will continue to work for me now }(\mathrm{M}=3.41 ; \mathrm{SD}=0.91)\end{array}$ & & \\
\hline \multirow{5}{*}{$\begin{array}{l}\text { Relaxed and } \\
\text { comfortable } \\
\text { atmosphere }\end{array}$} & 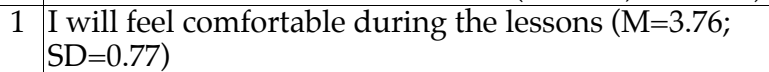 & \multirow[t]{5}{*}{0.825} & \multirow[t]{5}{*}{$\begin{array}{l}\mathrm{M}=3.77 \\
\mathrm{SD}=0.64\end{array}$} \\
\hline & $2 \begin{array}{l}\text { During the debriefings, the atmosphere will be } \\
\text { relaxed }(\mathrm{M}=3.64 ; \mathrm{SD}=0.77)\end{array}$ & & \\
\hline & 3 Embattled students will get help $(\mathrm{M}=3.70 ; \mathrm{SD}=0.92)$ & & \\
\hline & $\begin{array}{l}4 \text { I believe that the atmosphere will be relaxed during } \\
\text { the lessons }(M=3.99 ; S D=0.77)\end{array}$ & & \\
\hline & $\begin{array}{l}5 \begin{array}{l}\text { The atmosphere will motivate me to learn }(\mathrm{M}=3.66 \text {; } \\
\mathrm{SD}=0.95)\end{array}\end{array}$ & & \\
\hline
\end{tabular}

The results show that students' expectations concerning their academic self-perception $(\mathrm{M}=3.51 ; \mathrm{SD}=0.70)$ were moderately high. As the sum variable's name ("Confident and competent students") indicates, students were especially certain that they could manage different kinds of exercises $(\mathrm{M}=3.86$; $\mathrm{SD}=0.85)$ and that they would pass the course $(\mathrm{M}=3.73 ; \mathrm{SD}=0.84)$. "Relaxed and comfortable atmosphere" was used to describe the students' expectations of the atmosphere, which were quite high $(M=3.77 ; S D=0.64)$. Individual items indicated that most often students expected that the atmosphere would be relaxed $(\mathrm{M}=3.99 ; \mathrm{SD}=0.77)$ and comfortable $(\mathrm{M}=3.76 ; \mathrm{SD}=0.77)$ during the lessons, and that embattled students would get help $(\mathrm{M}=3.70 ; \mathrm{SD}=0.92)$. Although simulation exercises sometimes cause nervousness (Alinier, Hunt, Gordon \& 
Harwood, 2006; Cleave-Hogg \& Morgan, 2002), students in this study expected the atmosphere to be relaxed during the lessons, which is a prerequisite for good learning (e.g., Cassaday, Bloomfield \& Hayward, 2002). In simulation-based training, it is important that students be allowed to make mistakes without being ridiculed or humiliated. Especially in debriefing sessions, it is crucial that students are able to freely express their views and learn from their mistakes (Fanning \& Gaba, 2007).

\section{Differences in expectations between adult and young students}

The third research question was: Are there differences between the expectations of adult and young students? The respondents' mean age was 27 years; the youngest respondent was 19 years old and the oldest was 53. Therefore, before the analysis, the participants were divided into two age groups based on the distribution that is popular in statistics and labour markets in Finland (Herranen \& Penttinen, 2008): 1) Adult students ( $>25$ years old; $n=39 ; 40.2 \%$ ); and 2 ) Young students ( $\leq 25$ years old; $\mathrm{n}=58 ; 59.8 \%$ ). To determine whether there were statistically significant differences between adult and young students' expectations, the Kolmogorov-Smirnov test was used. For analysis, the sum variables were categorised into three categories so that values 1 and 2 described little expectations, and the values four and five described great expectations. Value three was a neutral value. Percentile distributions of the adult and young students with little or a lot of expectations regarding teaching, studying, learning, instructors, their academic self-perception, and atmosphere are presented in Figure 1.

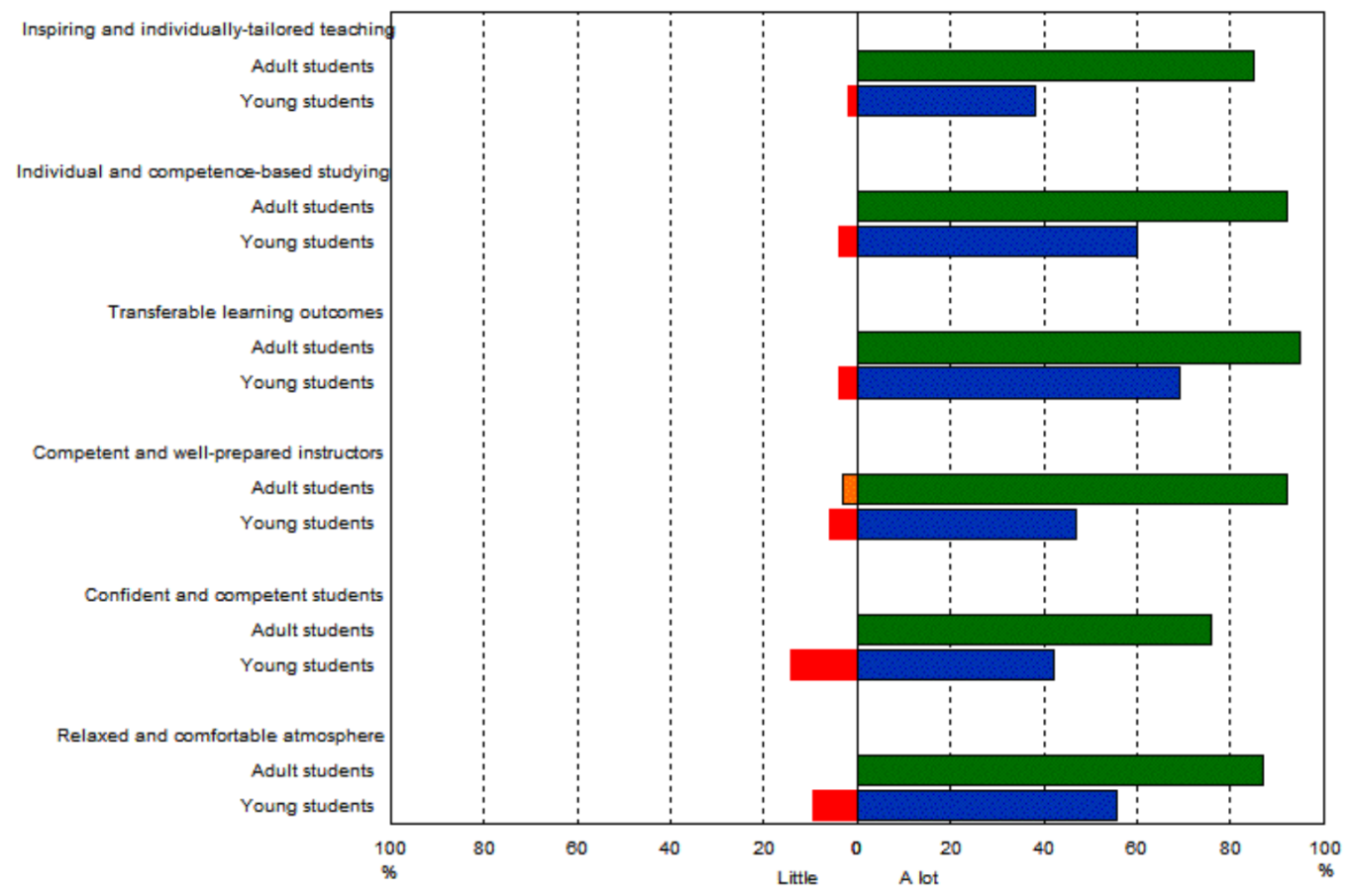

Figure 1: Percentages of adult and young students' expectations regarding teaching, studying, learning, instructor, academic self-perception, and atmosphere 
As Figure 1 indicates, adult students seemed to have higher expectations than young students. The most significant differences were found in expectations regarding teaching (K-S test $=.0469, \mathrm{p}=.000, \mathrm{p}<0.05)$ and instructors $(\mathrm{K}-\mathrm{S}$ test $=.0452, \mathrm{p}=.000$, $\mathrm{p}<0.05$ ). However, the adult students also expected more from studying (K-S test $=$ $.0321, \mathrm{p}=.023, \mathrm{p}<0.05)$, learning (K-S test $=.357, \mathrm{p}=.008, \mathrm{p}<0.05)$, their academic selfperception (K-S test $=.343, \mathrm{p}=.012, \mathrm{p}<0.05)$, and atmosphere $(\mathrm{K}-\mathrm{S}$ test $=.314, \mathrm{p}=.025$, $\mathrm{p}<0.05)$. This might be because the younger students did not have as much experience as the older students. In other words, they did not have as many experience-based expectations (Parasuraman et al., 1988). Therefore, they might have been uncertain about what to expect from VR, simulation-based training, and themselves as learners, as this younger student explained:

Because I am one of the few who have no field experience, I hope that the more experienced students do not throw their weight around, but that they understand my level and support me. I believe that with this group, this is possible. (Student, number 18)

\section{Discussion and concluding remarks}

This research aimed to describe the expectations of first-year healthcare students $(\mathrm{N}=97)$ regarding teaching, studying, and learning in VR and SBLEs. In addition, it measured students' expectations of their instructors, academic self-perception, and atmosphere. For these purposes, the DREEM questionnaire (Roff et al., 1997) and questionnaires that have been used to measure meaningful learning (Nevgi \& Löfström, 2005; Hakkarainen, 2007) were selected; however, they were revised for the purposes of this research in order to identify students' expectations. Additionally, a little space was provided for students to answer an open-ended question, which was used here to contribute to the quantitative analysis. Sixty-five items were transformed into six subscales. Each subscale's Cronbach's alpha was quite high, which indicates both an acceptable internal consistency and that the variables can be used to describe students' expectations (Nunnally, 1978). Although this study's results are consistent with the results of previous studies, there is a need for more investigations to be sure that this questionnaire can be used as a valid measure of students expectations. Men $(\mathrm{n}=15 ; 15.5 \%)$ and women $(\mathrm{n}=82 ; 84.5 \%)$ were both represented in different fields of education; thus the target group was quite consistent. Although the gender distribution was uneven, it followed the distribution normally found in healthcare education in Finland (e.g., Saarenmaa, Saari \& Virtanen, 2010). However, the uneven distribution of gender was the reason this study did not attempt to determine differences in expectations between the genders.

It is also acknowledged that this study was not profound. For example, academic selfperception is an extensive research field, so profound understanding of this concept could have been reached by studying it on its own (e.g., Valentine, DuBois \& Cooper, 2004). In addition to the questionnaires, the interviews could have provided additional information, for example, about the reasons the students did not expect much from their academic self-perception. However, this study provided us with useful information concerning students' expectations about learning in VR and SBLE, which could be used to develop a more user-centred pedagogical model and education for these environments.

As a result of the analysis, the sum variables expressing students' expectations of VR and SBLEs were named as follows: 
1. Inspiring and individually tailored teaching;

2. Individual and competence-based studying;

3. Transferable learning outcomes;

4. Competent and well-prepared instructors;

5. Confident and competent students (academic self-perception); and

6. A relaxed and comfortable atmosphere.

Overall, students had high expectations of the activities involving VR and SBLEs. In all cases, over half of the students expected quite a lot or a lot from the learning process that takes place in VR and SBLEs, while there were only a few students who expected nothing or little. The adult learners especially seemed to have high expectations, compared to younger students. Previous findings about students' expectations have also indicated that students have high expectations of their learning environment (Amin et al., 2009; Draper \& Louw, 2007; Miles \& Leinster, 2007). The results of this study indicate that students had, on average, the highest expectations regarding their learning and their instructors, although the difference between the means and standard deviations of the sum variables was small. Students particularly expected that what they learned would be transferable, so that after training in the learning environment they would be competent. The students also expected quite a lot from their instructors. It was important for students that instructors are competent and well prepared for teaching, and that they provide clear examples. These results place high demands on education and educators. Therefore, we should consider these expectations as advice, and take them into account when organising approaches to teaching and studying. Otherwise, unmet expectations could lead to dissatisfaction. Learning is also inherently individual (De Corte, 1995), and students in this study expected that teaching would be individually tailored and that studying would be selfdirected (cf. Keskitalo, Ruokamo \& Väisänen, 2011). Therefore, this study suggests that special attention should be paid to students' individuality.

Students' academic self-perception was the lowest of all sum variables, although it was still positive. One explanation could be that students were aware that they were going into a new school and that they were going to train in a new type of learning environment, which could unexpectedly reveal their level of competence (cf. CleaveHogg \& Morgan, 2002). Thus, at the same time, they were a little insecure about their skills and knowledge but were also quite positive that they could manage the exercises, pass the course, and be well prepared for their profession. On the other hand, $84.5 \%$ of the participants were female, and females have a tendency to underestimate their own performance (Chevalier, Gibbons, Thorpe, Snell \& Hoskins, 2009). This could be one reason why academic self-perception was the lowest sum variable. However, it seems that students had somewhat realistic perceptions of themselves as learners, which is a good prerequisite for learning. It is certainly better than having too positive or too negative a view about oneself as a learner, which could hamper learning (Chevalier et al., 2009; Valentine et al., 2004).

Nevertheless, emphasising reflection during teaching and learning could enhance students' awareness of their own level of competence as well as protect their emotional well-being (cf. Chevalier et al., 2009; Stringer \& Heath, 2008). As Barrows and Tamblyn (1980) have stated, students need to learn to recognise their own knowledge gaps what they know and what they do not know. Students' expectations of their learning atmosphere were also moderately high in this study. These expectations could be quite easily met, since previous researchers have stated that students enjoy learning in these 
environments (Holzman et al., 1995; Keskitalo et al., 2010; McManus \& Sieler, 1998; Moule et al., 2008).

This article is part of a larger study whose overall aim is to develop a pedagogical model for VR and SBLEs using a design-based research method, which is based on continuous cycles of design, enactment, analysis, and redesign (Brown, 1992; Designbased Research Collective, 2003). The first phase consisted of thematically interviewing teachers, the goal of which was to reveal the learning concepts, approaches to teaching, and educational tools that ENVI teachers use (Keskitalo, 2011). The purpose for the second phase was to find out what kinds of expectations students have regarding VR and SBLEs (see also Keskitalo, 2009). In a third phase, the purpose will be to design a pedagogical model according to the theory and results of the previous research, and to enact and redesign the model (Keskitalo et al., 2010). In the enactment phase, the purpose will be to also collect data regarding students' expectations, as well as to collect data from their experiences in these environments. This will enable us to detect the areas in which the students' expectations were not met. Eventually, an effective pedagogical model should be able to make teachers aware of the different choices and means available for teaching, and to help in the planning, realisation, and evaluation of education in VR and SBLEs.

\section{Acknowledgments}

The Finnish Funding Agency for Technology and Innovations and the European Development Regional Fund has provided the financing for this research as part of the Medi Peda II project. The author would like to thank the Medi Peda II project group and teachers for their helpful comments and guidance. The author also would like to thank the Doctoral Program for Multidisciplinary Research on Learning Environments (DPMRLE) for training and financial support.

\section{References}

Alinier, G., Hunt, B., Gordon, R. \& Harwood, C. (2006). Effectiveness of intermediate-fidelity simulation training technology in undergraduate nursing education. Journal of Advanced Nursing, 54(3), 359-369. http:/ / dx.doi.org/10.1111/j.1365-2648.2006.03810.x

Amin, Z., Tani, M., Eng, K. H., Samarasekara, D. D. \& Huak, C. Y. (2009). Motivation, study habits, and expectations of medical students in Singapore. Medical Teacher, 31(12), e560-e569. http: / / dx.doi.org/10.3109/01421590903193554

Barrows, H. S. \& Tamblyn, R. (1980). Problem-based learning: An approach to medical education. New York: Springer.

Bradley, P. (2006). The history of simulation in medical education and possible future directions. Medical Education, 40(3), 254-262. http: / / dx.doi.org/10.1111/j.1365-2929.2006.02394.x

Brown, A. L. (1992). Design experiments: Theoretical and methodological challenges in creating complex interventions. Journal of the Learning Sciences, 2(2), 141-178. [abstract only] http: / / www.cc.gatech.edu/lst/jls/vol2no2.html\#Article1

Cassaday, H. J., Bloomfield, R. E., \& Hayward, N. (2002). Relaxed conditions can provide memory cues in both undergraduates and primary school children. British Journal of Educational Psychology, 72(4), 531-547. http:/ / dx.doi.org/10.1348/00070990260377596

Chevalier, A., Gibbons, S., Thorpe, A., Snell, M. \& Hoskins, S. (2009). Students`academic selfperception. Economics of Education Review, 28(6), 716-727. http: / / dx.doi.org/10.1016/j.econedurev.2009.06.007 
Cleave-Hogg, D. \& Morgan, P. J. (2002). Experiential learning in an anaesthesia simulation centre: Analysis of students' comments. Medical Teacher, 24(1), 23-26. http: / / dx.doi.org/10.1080/00034980120103432

Cobb, S. \& Fraser, D. S. (2005). Multimedia learning in virtual reality. In R. E. Mayer (Eds.), The Cambridge handbook of multimedia learning (pp. 525-548). Cambridge: Cambridge University Press.

Design-Based Research Collective (2003). Design-based research: An emerging paradigm for educational inquiry. Educational Researcher, 32(1), 5-8. http: / / www.jstor.org/stable/3699927

De Corte, E. (1995). Fostering cognitive growth: A perspective from research on mathematics learning and instruction. Educational Psychologist, 30(1), 37-46. http: / / dx.doi.org/10.1207/s15326985ep3001_4

Dieckmann, P., Gaba, D. \& Rall, M. (2007). Deepening the theoretical foundations of patient simulation as social practice. Simulation in Healthcare, 2(3), 183-193. http: / / dx.doi.org/10.1097/SIH.0b013e3180f637f5

Draper, C. \& Louw, G. (2007). What is medicine and what is a doctor? Medical students' perceptions and expectations of their academic and professional career. Medical Teacher, 29(5), e100-e107. http:/ / dx.doi.org/10.1080/01421590701481359

Fanning, R. M. \& Gaba, D. M. (2007). The role of debriefing in simulation-based learning. Simulation in Healthcare, 2(2), 115-125. http:/ / dx.doi.org/10.1097/SIH.0b013e3180315539

Gaba, D. M. (2004). The future vision of simulation in health care. Quality and Safety in Health Care, 13(1), i2-i10. http: / / dx.doi.org/10.1136/ qshc.2004.009878

Hakkarainen, P. (2007). Promoting meaningful learning through the integrated use of digital videos. Doctoral dissertation, Rovaniemi, Finland: University of Lapland Printing Centre.

Haukkamaa, J., Yliräisänen-Seppänen, P. \& Timonen, E. (2010). Characteristics of value co-creation in a learning environment by service design and service-dominant logic frameworks. ServDes : Service design and innovation conference (2nd: Linköping). http: / / www.servdes.org/pdf/haukkamaa-yliraisanenseppanen-timonen.pdf

Herranen, J. \& Penttinen, L. (2008). Aikuisopiskelijalähtöistä ohjausta etsimässä. [Looking for adult-centered instruction]. In M. Lätti, \& P. Putkuri (Eds.), Ohjaus on kuin tekisi palapeliä Näkökulmia aikuisopiskelijan ohjaukseen ammattikorkeakoulussa. [Instruction like making a puzzle Views to adult learners` instruction in universities of applied sciences] (pp. 9-24). Tampere: Juvenes Print.

Higgs, B., Polonsky, M. J. \& Hollick, M. (2005). Measuring expectations: Forecast vs. ideal expectations. Does it really matter? Journal of Retailing and Consumer Services, 12(1), 49-64. http: / / dx.doi.org/10.1016/j.jretconser.2004.02.002

Hmelo-Silver, C. E. (2004). Problem-based learning: What and how do students learn? Educational Psychology Review, 16(3), 235-266. http: / / dx.doi.org/ 10.1023/B:EDPR.0000034022.16470.f3

Hmelo-Silver, C. E. \& Barrows, H. S. (2006). Goals and strategies of a problem-based learning facilitator. The Interdisciplinary Journal of Problem-based Learning, 1(1), 21-39. http: / / docs.lib.purdue.edu/ijpbl/vol1/iss1/4

Holzman, R. S., Cooper, J. B., Gaba, D. M., Philip, J. H., Small, S. D. \& Feinstein, D. (1995). Anesthesia crisis resource management: Real-life simulation training in operating room crises. Journal of Clinical Anesthesia, 7(8), 675-687. http:/ / dx.doi.org/10.1016/0952-8180(95)00146-8

Issenberg, S. B., McGaghie, W. C., Petrusa, E. R., Gordon, D. L. \& Scalese, R. J. (2005). Features and uses of high-fidelity medical simulations that lead to effective learning: A BEME systematic review. Medical Teacher, 27(1), 10-28. http: / / dx.doi.org/10.1080/01421590500046924

Jonassen, D. H. (1995). Supporting communities of learners with technology: A vision for integrating technology with learning in schools. Educational Technology, 35(4), 60-63. 
Joyce, B., Calhoun, E. \& Hopkins, D. (2002). Models of learning - Tools for teaching. (2nd ed.) Buckingham: Open University Press.

Kansanen, P., Tirri, K., Meri, M., Krokfors, L., Husu, J. \& Jyrhämä, R. (2000). Teachers' pedagogical thinking: Theoretical landscapes, practical challenges. American University Studies. Series XIV, Educational vol. 47. New York: Peter Lang.

Keskitalo, T. (2009). Students' expectations and teachers' approaches - A starting point for designing a pedagogical model for virtual and simulated learning environments. Presentation given at the AERA (American Educational Research Association) 2009 Annual Meeting, 16 April 2009, San Diego, California.

Keskitalo, T. (2011). Teachers' conceptions and their approaches to teaching in virtual reality and simulation-based learning environment. Teachers and Teaching: Theory and Practice, 17(1), 131147. http:/ / dx.doi.org/10.1080/13540602.2011.538503

Keskitalo, T., Ruokamo, H. \& Väisänen, O. (2010). How does the facilitating, training and learning model support characteristics of meaningful learning in a simulation-based learning environment from facilitators' and students' perspectives? Proceedings of ED-Media 2010: World Conference on Educational Multimedia, Hypermedia \& Telecommunications. June 27-July 1, 2010, Toronto, Canada (pp. 1736-1746).Chesapeake,VA: AACE. http:/ / editlib.org/p/34874

Keskitalo, T., Ruokamo, H. \& Väisänen, O. (2011). Facilitators' and students' conceptions of teaching and learning in simulation-based learning environment. In T. Bastiaens \& M. Ebner (Eds.), Proceedings of World Conference on Educational Multimedia, Hypermedia and Telecommunications 2011. June 27-July 1, 2011, Lisbon, Portugal (pp. 2215-2224). Chesapeake, VA: AACE. http: / / www.editlib.org/p/38168

Kneebone, R. (2003). Simulation in surgical training: Educational issues and practical applications. Medical Education, 37(3), 267-277. http:/ / dx.doi.org/10.1046/j.1365-2923.2003.01440.x

Kneebone, R. L., Scott, W., Darzi, A. \& Horrocks, M. (2004). Simulation and clinical practice: Strengthening the relationship. Medical Education, 38(10), 1095-1102. http: / / dx.doi.org/10.1111/j.1365-2929.2004.01959.x

Knowles, M. S. (1975). Self-directed learning: A guide for learners and teachers. Cambridge: Englewood Cliffs.

Kolb, D. A. (1984). Experiential learning. Experiences as a source of learning and development. Englewood Cliffs. NJ: Prentice Hall.

Lave, J. \& Wenger, E. (1991). Situated learning: Legitimate peripheral participation. Cambridge: Cambridge University Press.

Loke, S-K., Blyth, P. \& Swan, J. (2012). In search of a method to assess dispositional behaviours: The case of Otago Virtual Hospital. Australian Journal of Educational Technology, 28(3), 441-458. http: / / www.ascilite.org.au/ajet/ajet28/loke-1.html

McManus, E. S. \& Sieler, P. A. (1998). Freedom to enjoy learning in the 21st century: Developing an active learning culture in nursing. Nurse Education Today, 18(4), 322-328. http: / / dx.doi.org/ 10.1016/S0260-6917(98)80050-6

Miles, S. \& Leinster, S. J. (2007). Medical students' perceptions of their educational environment: Expected versus actual perceptions. Medical Education, 41(3), 265-272. http: / / dx.doi.org/10.1111/j.1365-2929.2007.02686.x

Moule, P., Wilford, A., Sales, R. \& Lockyer, L. (2008). Student experiences and mentor views of the use of simulation for learning. Nurse Education Today, 28(7), 790-797. http: / / dx.doi.org/10.1016/j.nedt.2008.03.007

Nevgi, A. \& Löfström, E. (2005). The quality of online learning: Teachers' and students' evaluation of meaningful learning experiences in web-based course. In S. Kiefer, J. Michalak, A. Sabanci \& K. Winter (Eds.), Analysis of educational policies in comparative educational perspective (pp. 187-203), Linz: Trauner.

Nunnally, J. C. (1978). Psychometric theory. (2nd ed.). New York: McGraw-Hill. 
O'Connell, V. A. \& Gupta, J. (2006). The premedical student: Training and practice expectations. Medical Education Online, 11:12, 1-10. http://med-ed-online.net/index.php/meo/article/view/4590

Parasuraman, A., Zeithaml, V. A. \& Berry, L. L. (1988). SERVQUAL: A multiple-item scale for measuring customer perceptions of service quality. Journal of Retailing, 64(1), 12-40. http: / / www.msi.org/ publications / publication.cfm?pub=190

Rall, M. \& Dieckmann, P. (2005). Simulation and patient safety. The use of simulation to enhance patient safety on a system level. Current Anesthesia and Critical Care, 16(5), 273-281. http: / / dx.doi.org/ 10.1016/j.cacc.2005.11.007

Ramani, S. (2006). Twelve tips to promote excellence in medical teaching. Medical Teacher, 28(1), 19-23. http: / / dx.doi.org/ 10.1080/01421590500441786

Roff, S., McAleer, S., Harden, R. M., Al-Qahtani, M., Ahmed, A. U., Deza, H., Groenen, G. \& Primparyon, P. (1997). Development and validation of the Dundee Ready Education Environment Measure (DREEM). Medical Teacher, 19(4), 295-299. http: / / dx.doi.org/10.3109/01421599709034208

Rogoff, B. (1990). Apprenticeship in thinking. New York: Oxford University Press.

Rosen, K. R. (2008). The history of medical simulation. Journal of Critical Care, 23(2), 157-166. http: / / dx.doi.org/10.1016/j.jcrc.2007.12.004

Saarenmaa, K., Saari, K. \& Virtanen, V. (2010). Opiskelijatutkimus 2010. Korkeakouluopiskelijoiden toimeentulo ja opiskelu. [Student research 2010. Higher education students living and studying.] Opetus- ja kulttuuriministeriön julkaisuja 2010:18.

Shewchuk, R. M., Schmidt, H. J., Benarous, A., Bennett, N. L., Abdolrasulnia, M. \& Casebeer, L. L. (2007). A standardized approach to assessing physician expectations and perception of continuing medical education. Journal of Continuing Education in the Health Professions, 27(3), 173-182. http: / / dx.doi.org/10.1002/ chp.121

Stringer, R. W. \& Heath, N. (2008). Academic self-perception and its relationship to academic performance. Canadian Journal of Education, 31(2), 327-345. http: / / www.jstor.org/stable/ 20466704

Tynjälä, P. (1999). Towards expert knowledge? A comparison between a constructivist and a traditional learning environment in the university. International Journal of Educational Research, 31(5), 357-442. http: / / dx.doi.org/10.1016/S0883-0355(99)00012-9

Uljens, M. (1997). School didactics and learning. Hove, East Sussex: Psychology Press.

Valentine, J. C., DuBois, D. L. \& Cooper, H. (2004). The relation between self-beliefs and academic achievement: A meta-analytic review. Educational Psychologist, 39(2), 111-133. http: / / dx.doi.org/10.1207/s15326985ep3902_3

Vygotsky, L. (1978). Mind in society: The development of higher psychological processes. Cambridge: Harvard University Press.

Østergaard, H. T., Østergaard, D. \& Lippert, A. (2004). Implementation of team training in medical education in Denmark. Quality and Safety in Health Care, 13(1), i91-i95. http: / / dx.doi.org/10.1136/ qshc.2004.009985

Author: Tuulikki Keskitalo MEd. PhD student, Researcher Centre for Media Pedagogy, Faculty of Education

University of Lapland, PO Box 122, FI-96101 Rovaniemi, Finland

Email: tuulikki.keskitalo@ulapland.fi Web: http: / / tuulikkikeskitalo.wordpress.com/

Please cite as: Keskitalo, T. (2012). Students' expectations of the learning process in virtual reality and simulation-based learning environments. Australasian Journal of Educational Technology, 28(5), 841-856.

http: / / www.ascilite.org.au/ajet/ajet28/keskitalo.html 